\title{
Toward Analytic Theology: An Itinerary
}

\author{
GEORG GASSER \\ Innsbruck University \\ Georg.Gasser@uibk.ac.at
}

\begin{abstract}
In this paper I aim at explaining how analytic philosophical theology developed into a thriving field of research. In doing so, I place analytic philosophical theology into a larger intellectually narrative that is deeply influenced by the philosophy of Enlightenment. This larger framework shows that analytic philosophical theology aims at providing answers to concerns raised by a philosophical tradition that shaped fundamentally the making of our modern Western secular world.
\end{abstract}

Keywords: analytic philosophical theology; evidentialist objection; verificationism; reformed epistemology; the rationality of religious belief.

\section{Introduction}

Analytic theology is an outgrowth of analytic philosophy of religion. Often both terms are used interchangeably; there is no clear conceptual differentiation to hand, and it seems insignificant to demand one. The transition from analytic philosophy of religion to analytic theology is fluid. One might say that, as a discipline, analytic theology uses the methodology of analytic philosophy to address issues pertaining explicitly to theology. For reasons of simplicity I will only speak of analytic philosophical theology when no specific distinction between philosophy and theology is required. 
My thesis is that analytic theology is the most recent stage of a continuous intellectual debate - one might also say the next natural step - whose development stems from the analytic tradition of the 1950s (see Pouviet 2011). ${ }^{1}$

However, a proper understanding requires stepping farther back yet, because prominent strands of thought in the analytic tradition can only accurately be understood in the light of issues originating at the beginning of modern Western philosophy. Thus, I place the development of analytic philosophical theology into a larger narrative. This approach is aimed to show that analytic philosophical theology is by no means the whimsical invention of religiously partisan philosophers in the second half of the $20^{\text {th }}$ century. Rather, it is the outflow of, and response to, a powerful philosophical tradition that played a crucial role in shaping the modern Western secular world.

Some philosophers and theologians might find such an approach surprising, for one of the many objections against analytic thought is precisely its supposed a-historicity. As I shall argue, however, this is a substantial oversimplification which stands in need of revision. For a comprehensive picture of analytic philosophical theology I think that a formalist characterization in terms of style and method must be supplemented with a narrative that points out why many proponents of a philosophical tradition that was known for its predominately anti-metaphysical and anti-theological origins have begun to conduct discussions about religion.

My argument proceeds in five steps:

First: I begin with the Vienna Circle and the verificationist criterion of meaning, which in principle prevents any substantial philosophical discussion of religious topics.

Second: I discuss how the verificationist criterion died the silent end of a philosophical idea that proved to be untenable and how, in a parallel

The history of philosophy is a tricky business, based inevitably on simplifications. There are studies showing that what is now called analytic philosophical theology is not a genuinely Anglo-American product but that discussions on religion, logic, and language are to be found in the "Cracow-circle" in Poland in the 1930s. The tragedy of WWII led to an abrupt end of this movement, however. The postwar work of the Polish-Swiss Dominican Józef Bochenski is a later fruit of these prewar thoughts. 
process from the 1950s onward, philosophers interested in religion started to reflect on the peculiarities of religious language. The infancy of analytic philosophical theology was party to a lively debate about the logic of religious language, which was additionally spurred on by the publication of Wittgenstein's later writings.

Third: In what we might think of as its adolescence, analytic philosophical theology was primarily concerned with epistemological topics in the 1960 s to 1980 s. A proper understanding of this concern requires reference to Locke and Kant, because their proposals for rationally justifying religious belief acted as foils against which analytic philosophers of religion argued.

Fourth: From the late 1980s onward, analytic philosophical theology attained maturity. It bore witness to a proliferation of questions - epistemological, logical, metaphysical and ethical - pertaining to religious thought. A natural consequence of this proliferation has been the increasing occupation with topics lying at the heart of (Christian) theological doctrine.

Fifth: I conclude by commenting briefly on various criticisms raised against analytic philosophical theology.

\section{The prehistory: Logical Positivism}

In August 1929 a group of philosophers and scientists in Vienna went public with a manifesto dedicated to what the authors called a "scientific conception of the world" (Wissenschaftliche Weltauffassung 1929). This conception was based on the idea that a statement is meaningful only if it is either empirically verifiable or logically necessary. Consequently, there is a sharp distinction between the following two kinds of statements: Empirical statements on the one hand, and metaphysical and theological statements on the other. Logical analysis reveals that the meaning of the former is expressed by the reduction of complex concepts to basic ones referring directly to empirical data. As for the latter said the manifesto, logical analysis reveals that they lack any clear meaning, because neither 
a reduction to precise empirically grounded basic concepts is available nor are they logically necessary Accordingly, only empirical statements refer to genuinely theoretical content and are about reality; metaphysical and theological statements, by contrast, may express "only" an existential attitude towards life. As such they have meaning in the sense of being able to influence one's feelings, beliefs, or behavior but not in the sense of being true or false.

This sketchy characterization suffices to disclose the devastating consequences of the scientific conception on metaphysical and theological thoughts. Such thoughts neither state facts that can ultimately be verified (or falsified) by sensory experience, nor do they explicate the meaning of concepts and propositions. They are cognitively meaningless pseudo-statements according to the proposed verificationist criterion of meaning by logical analysis.

This result is nicely illustrated by Carnap's The Elimination of Metaphysics Through Logical Analysis of Language. After attempting to analyze the concept "God", he draws the following conclusion:

To be sure, it often looks as though the word "God" had a meaning even in metaphysics. But the definitions which are set up prove on closer inspection to be pseudo-definitions. They lead either to logically illegitimate combinations of words [...] or to other metaphysical words [...] but in no case to the truth conditions of its elementary sentences (Carnap 1932/1959, 66).

He closes the paragraph as follows:

The alleged statements of metaphysics which contain such words have no sense, assert nothing, are mere pseudo-statements (Carnap 1932/1959, 67).

It is no wonder that this intellectual climate of the so-called logical positivist movement was no fertile soil for any form of philosophy of religion. It is hard to imagine a harsher verdict on religious assertions than that they are not only false but utterly meaningless. Since this verdict applied not only to a specific system of religious thought (say, a particularly su- 
perstitious version of theistic popular belief) or to a determinate class of religious sentences (say, Scriptural verses openly advocating brutal violence against innocent people) but unanimously to all religious assertions whatsoever, an effective defense against this attack was hardly available from the standpoint of religion itself. Any serious analytic philosophical theology could not even get off the ground as long as the verificationist criterion of meaning was widely accepted.

\section{Infancy: The demise of the verificationist criterion of meaning}

Things changed quickly, however, once the verificationist criterion came more and more under attack. The reasons for the rising unpopularity of this criterion are manifold: On the one hand, it became obvious that no satisfactory concept of empirical verifiability could be established. As a consequence, no clear criterion for distinguishing meaningful from meaningless statements was available. One the other hand, the verificationist criterion was observed to be so strict as to be directed against unsuspicious common scientific statements as well, thus making science itself impossible (Hempel 1950). ${ }^{2}$ Finally, advocates of so-called ordinary language philosophy argued that the verificationist criterion ignores that meaningful linguistic expressions are not confined to descriptive statements alone but include imperative, interrogative or performative utterances as well. ${ }^{3}$

Simultaneously, philosophers interested in religion took up the challenge posed by logical positivism. Particularly telling in this context is a controversy on "theology and falsification" which took place in the Oxford journal University in 1950/51 and was reprinted in New Essays in Philosophical Theology (Flow and MacIntyre 1955). The initial impulse came from

2 Hempel argued that the verifiability criterion implies that universal generalizations are not meaningful. Thus, the proposed criterion eliminates the formulation of general laws, which is a primary aim of scientific research.

3 It might be noted that these criticisms are purely philosophical and that some of them even stem from thinkers sympathetic to the positivist movement, such as Hempel. 
Anthony Flew, who presented the following parable (originally going back to a tale of John Wisdom): Two men discover a garden in the deep jungle. One man, the believer, is convinced that a gardener planted the garden; his friend, the skeptic, disagrees. They decide to find out who is right and set a watch. No gardener is seen; even after guarding the garden with all imaginable detection devices, no trace of a gardener was observed. As a result, the sceptic comes to the firm conclusion that there is no gardener; the believer, however, sticks to his belief that this garden is evidence of a gardener, but adds the qualification that the gardener apparently is invisible, intangible, scientifically undetectable and elusive. For Flew this parable shows that "a fine brush hypothesis may thus be killed by inches, the death by a thousand qualifications." (Flew 1955, 97).

According to Flew, this is a particular danger for theological statements. They start as assertions about God's plan for the world or God's love for creation. However, there are no clear criteria at hand indicating what would count as their falsification. What would falsify the statement that "p exists as an invisible, intangible, scientifically undetectable and elusive being", but not the statement that "p does not exist at all"? The difference between them seems to be eliminated, since the qualifications in the former statement make it apparently compatible with (almost) any state of affairs.

R. M. Hare responds to Flew with a parable of his own (Hare 1955): A student is convinced that all dons plan to murder him. Moreover, all attempts by the student's friends to show that his conviction is baseless fail. The student interprets the friendly behavior of the various dons introduced to him as a particularly sophisticated plan to think himself safe so that the plan to murder him can be carried out even more easily. Hare uses this parable to argue that religious belief should not be treated as a kind of explanatory hypothesis as Flew suggests with his use of the parable. Rather, religious belief expresses what Hare calls a blik, which means roughly the way in which a person fundamentally looks at reality. The poor student has a certain blik at reality because he experiences the dons of his college as a threat for his personal safety. Even though there is no way to verify 
or falsify a blik, it makes a huge difference which blik a person adopts - as the parable illustrates. There are more and less adequate bliks, and it is important to have an adequate one.

B. Mitchell, another respondent to Flew, counters Flew with yet another parable (Mitchell 1955, 103-104). He imagines that, one night, a member of a resistance army meets a stranger who deeply impresses him. The stranger says that he belongs to the resistance army too, and is even one of its commanders. The stranger tells the partisan to trust him no matter what happens, and the partisan is utterly convinced that the stranger is loyal, sincere and upright. They meet again and again but it is difficult to makes sense of the stranger's overall behavior: Sometimes he fights on the side of the resistance army, and sometimes he is seen with members of the occupying force. Sometimes the stranger provides the help asked for, sometimes he fails to reply even though the resistance forces are in a most difficult situation.

The partisan does not allow anything to count decisively against his belief that the stranger is not on the side of the resistance army, because he is committed to his promise to trust the stranger. However, it is utterly clear to him that the stranger's behavior is ambiguous. He understands why some of his partisan friends refuse to collaborate with the stranger, namely because they fear that in reality he works for the occupation army's secret service.

Mitchell uses this parable to illustrate several claims. First, religious belief is based on a positive encounter with the divine. Second, this encounter gives rise to an attitude of trusting God, which, however, is subject to doubt and open to criticisms. Thus, theological utterances are assertions after all and there is plenty of evidence against the (central Christian) assertion that a good and loving God exists - just think of the problems of evil and divine hiddenness to which Mitchell alludes in his parable. Third, the believer trusting God will not allow such evidence to count decisively against his belief. However, fourth, at one point - which is hard to predict - the evidence against God might become so strong that the believer's trust dissipates or becomes a mere vacuous formula which ceases to influence his life. 
In his reply to Mitchell, Flew admits that theologians usually accept the view that many reasons speak against the believer's commitment to trust God but that they nevertheless insist "that there is - there must be - some explanation which will show that, in spite of appearances, there really is a God who loves us." (Flew 1955, 107).

For Flew, this kind of reply is ultimately a failure; the reason is simply that God is very unlike a human being. Mitchell's partisan can reasonably explain the stranger's ambiguous behavior by saying that the stranger does not know the real situation of the resistance army, that he lacks the power to help, etc. This response is not open to the theologian, however, for God is supposed to be omnipotent, omniscient and morally perfect. Thus, the theologian "will have to resort to the avoiding action of qualification. And there lies the danger of that death by a thousand qualifications [...].” (Flew 1955, 107).

This delineation of the debate suffices to pick out two important points for our discussion:

First, Hare and Mitchell stress the fundamental difference between theological and scientific discourse. Theological discourse is not concerned primarily with explanation but rather with giving voice to a certain "form of life". In other words, they argue that language has another function beside describing and explaining: an essential function of religious language in particular is to express a person's commitment to trust a God even though this God remains strange and incomprehensible to us in many respects.

When the discussion in University took place, Wittgenstein's Philosophical Investigations were not published yet. ${ }^{4}$ It must not be overlooked, however, that the aim of liberating our understanding of language from the strictures of verificationism was already “in the air”. Hare's concept of a blik has structural similarities with Wittgenstein's notion of a language game. The student in Hare's parable perceives the world from within his blik, similarly to the way in which a person is within her language game and her corresponding form of life. Of course, a radical interpretation of

4 The first publication was in 1953 together with G.E.M. Anscombe's translation into English. 
Wittgenstein's language game leads to some form of linguistic pluralism or relativism, for we end up with many incommensurable language games and no external method for evaluating their adequacy. One need not go this far, however; for, as Mitchell argues, religious belief is neither above criticism nor beyond rational argumentation; on the contrary, it makes good sense to assume that there are reasons for and against one's religious belief.

Second, a careful reading of Flew's reply to Hare and Mitchell shows that his discussion goes in a rather traditional direction. Flew's main argument emphasizes that theological discourse ought to be interpreted realistically (against Hare's blik proposal), but (against Mitchell) the classical divine attributes seem to offer few explanations help for responding to the criticisms raised against belief in God. Flew's claim is no longer that theological assertions per se are meaningless; rather they are seen to be false: In light of all the evil in the world, an assertion like "God is our loving father" appears to be false.

To summarize: The search for the verificationist criterion of meaning receded, with the criterion itself, into gradual oblivion. Unsurprisingly, the decline of logical positivism in the 1950s had a liberating effect for the development of analytic philosophical theology. The charge that its assertions are meaningless lost its intimidating force. From then on one had to argue about the truth or falsity of religious statements by giving reasons; a simple remark that such statements are devoid of any cognitive meaning was no longer accepted.

Nicholas Wolterstorff remarks in a recent article (Wolterstorff 2009) that the demise of logical positivism had another far-reaching effect as well: A main strand of modern philosophy was occupied with the question of delineating the knowable from the non-knowable: Think, for instance, of Descartes's project to delineate the dubitable from the indubitable, Hume's skepticism about supposedly true propositions about immediate sense impressions, or of Kant's investigation of the boundaries between the phenomenal and the noumenal. Verificationism can be seen as another such project of delineation. Its ultimate failure had the consequence that "deep skepticism reigns among analytic philosophers concerning all grand pro- 
posals for demarcating the thinkable from the unthinkable, the assertible from the non-assertible." (Wolterstorff 2009, 157).

That philosophers have ceased to be concerned with the search for such a demarcation is, according to Wolterstorff, among the primary reasons why philosophical theology has begun to flourish in the analytic tradition.

\section{The historical context of analytic philosophical theology}

Wolterstorff's hint is worthy of further investigation, for it helps us understand the larger stream of thought in which analytic philosophical theology is embedded. This stream of thought brings us back to the late $17^{\text {th }}$ century and the $18^{\text {th }}$ century (Wolterstorff 1996; Wolterstorff 2010). In order to see the importance of the philosophical ideas developed in that time for thinking about religion in subsequent centuries, it behoves us to compare them with the heyday of philosophical thinking about religion: medieval philosophical theology. In medieval times, philosophical and theological thinking was text-based. There was a traditional and continuously growing canon of philosophical and theological literature which each generation of scholars had to study and comment on. Although various schools developed at different universities, monasteries and religious orders, and dissonances and inconsistencies in the literature under investigation were recognized; this diversity of views concerning the hermeneutical challenges of understanding the texts was not regarded as anything threatening. Rather, the growing body of literature on those texts was largely seen as a single source of one and same wisdom which carefully had to be extracted. Wolterstorff notes:

Of course, it was recognized that there were heresies, errors, and disputed questions; [...]. Nonetheless, the conviction remained that if one assigned the proper priorities among the texts (with the Bible being preeminent), selected the right senses, used the appropriate strategies of interpretation, and made the right distinctions, a richly articulated body of truth would come to light. St. Paul and Virgil, Aristotle and Augustine, would all be seen to fit together (Wolterstorff 1996, 2). 
In the late $17^{\text {th }}$ century the situation was altogether different: Europe was highly fragmented, both politically and religiously. Fierce wars destroyed large areas in France, Germany and England. Europe was divided not only between Catholics and Protestants, but Protestantism itself was fragmented into smaller and often antagonistic groups many of which fought each other. In effect, a series of religious wars over the right interpretation of texts and traditions was taking place. In such a situation of religious, moral and intellectual crisis, the idea of one unified body of knowledge handed down by one unified tradition as basis for a common understanding was no longer credible. There was no one unified tradition anymore but many different mutually exclusive traditions. Thus, it is no surprise that intellectuals sought another basis which could serve as a common starting point of discussion acceptable by and accessible to every rational person.

Locke was among these intellectuals. For him this situation of fragmentation and conflict was a symptom of the deeper problem: People unreflectively defend their own particular tradition, rather than further investigating whether their defense is justified (Conduct, § 10, 10-18). To overcome this deplorable situation, people must follow the voice of reason by aiming to discover the fundamental and substantial truths upon which all others are based. Locke writes:

There are fundamental truths that lie at the bottom, the base that a great many others rest on and are held together by. These are teeming with content with which they furnish the mind, and-like the lights of heaven-are not only beautiful and entertaining in themselves but bring to light other things that without them couldn't be seen or known. An example is Newton's admirable discovery that all bodies gravitate towards one another, which may be counted as the basis of natural philosophy. He has astonished the learned world by showing how much this helps us to understand the great frame of our solar system; we don't yet know how much further it would guide us in other things if rightly pursued (Conduct, § 43).

What Locke proposes is a version of classical foundationalism: The acceptance of a certain belief should depend on fundamental beliefs whose truth 
is certain or (at least) very probably true. This procedure holds not only for knowledge of the natural world but also of religion. Although Locke thinks that our minds are narrow, prone to mistakes and capable of grasping relatively few truths, he is no skeptic, for he thinks that every rationally endowed creature has the capacity to grasp the fundamental religious truths. He remarks:

The works of nature and the words of revelation display it to mankind in characters so large and visible that those who aren't entirely blind can read them and see the first principles and most necessary parts of theology; and from there they may be able-time and energy permitting-to go on to the more abstruse parts of it, and penetrate into those infinite depths filled with treasures of wisdom and knowledge (Conduct, § 23, 12-20).

Locke takes it to be our duty as rational beings to thoroughly assess whether a believed divine revelation is really of divine origin or is merely an illusion, and says that the tool for doing so is reason. Locke is confident that any divine revelation is evidentially embedded; that is, that the revelation is not immediately directed to the addressee but rather is mediated by corresponding evidence which the addressee can employ reason to assess. Locke states:

[...] no proposition can be received for divine revelation, or obtain the assent due to all such, if it be contradictory to our clear intuitive knowledge. Because this would be to subvert the principles and foundations of all knowledge, evidence, and assent whatsoever (Essay, IV, xviii, 5).

He continues that

reason is the proper judge; and revelation, though it may, in consenting with it, confirm its dictates, yet cannot in such cases invalidate its decrees: nor can we be obliged, where we have the clear and evident sentience of reason, to quit it for the contrary opinion, under a pretence that it is matter of faith [...] (Essay, IV, xviii, 6). 
And he concludes:

Credo, quia impossibile est: I believe, because it is impossible, might, in a good man, pass for a sally of zeal; but would prove a very ill rule for men to choose their opinions or religion by (Essay, IV, xviii, 11).

These few passages from Locke lay open the foundationalist thrust of his argument. Religious beliefs are not of the sort to form a part of the basis of our system of justified beliefs. Religious beliefs are higher-order - they belong to the upper levels of our belief-system and are therefore in need of support by self-evident or clear and evident to the senses non-religious beliefs in the epistemic basis. The ideal is a system of justified true beliefs based on beliefs in propositions that are accessible to all people who use their faculties of reason in an appropriate and unbiased way. This basis provides us with a secure position from which to begin to investigate other issues on which reason has a less firm grasp - such as religious matters. Thus, Locke's proposal is the ideal of a rationally grounded religion (Wolterstorff 2010, 23).

This view overlaps to a good extent with Kant's own ideal, derived from his analysis of possible human experience and knowledge. According to Kant, anything outside the realm of our experience, that is, outside space and time as the two pure forms of our intuition, is beyond our ability to know. We can have no cognition ("Erkenntnis") of supersensible entities; thus any knowledge of entities like God or an (immaterial) soul is unavailable to us. It is important to underline that Kant does not think that we are unable to reflect in a sensible manner about the supersensible. We can form ideas about it and we can check whether these are construed consistently and coherently. Thus, the challenge is not that religious (or metaphysical) doctrines are unintelligible because they refer to the supersensible. Rather, the problem is that our thinking about this realm has no foothold in our experience and thus that we lack any clear methods for adjudicating between competing ideas. We cannot sensibly claim to have cognition of God or have witnessed a miracle, because we have no means 
to test the veracity of claims about entities outside space and time. Nevertheless, Kant underlines that human reason has a natural inclination to transcend its boundaries of experience, because it only finds peace once it arrives at a self-subsisting systematic outlook. He writes:

Reason is driven by a propensity of its nature to go beyond its use in experience, to venture to the outermost bounds of all cognition by means of mere ideas in a pure use, and to find peace only in the completion of its circle in a self-subsisting systematic whole. ${ }^{5}$

Kant contends that it is natural and perhaps even rationally inevitable to postulate supersensible entities which serve as capstones for ultimate and complete explanations of a given subject matter. The possible acceptance of such entities neither qualifies as knowledge (as indicated above); nor does it fall under a weaker form of assent, opinion ("Meinung"), for it is based upon the weighing of evidential and theoretical reasons for and against their truth.

However, Kant acknowledges a third mode of holding-to-be-true ("Fürwahrhalten"), which is faith. Faith is justified assent, though its justification is different from knowledge and opinion, for it is not rooted in experience and theoretical considerations but in the needs of practical reason. The idea is that, within the realm of theoretical reason, speculations about supersensible entities are possible but lack any rationally appropriate criterion of evaluation; in the realm of practical reason, by contrast, direction and guidance is provided by pragmatic needs. Kant writes:

When I compare all the transcendental Ideas [...] to produce the thing (be it knowledge or fiction) called metaphysics, I think I perceive that the aim of this natural tendency is, to free our notions from the fetters of experience and from the limits of the mere contemplation of nature so far as at least to open to us a field containing mere objects for the pure understanding, which no sensibility can reach, not indeed for the purpose of speculatively occupying ourselves with them (for there we can find no ground to stand on), but because practical

5 Critique of Pure Reason (A797/B825). 
principles, which, without finding some such scope for their necessary expectation and hope, could not expand to the universality which reason unavoidably requires from a moral point of view (Prolegomena § 60).

It is not theoretical but practical reason which justifies us in assuming an objective reality of ideas that transcend our experience; this assumption takes the form of postulates which make it reasonable to think that the highest good, a synthesis of morality and happiness, will obtain. As finite moral agents living under the obligation of the moral law we face the needs of practical reason, whose objective structure can be known by adequate reflection. ${ }^{6}$

I would like to underline two points of particular importance for our discussion: First, rationally grounded belief - faith - is epistemologically rooted in the architecture of man's practical reason. Second, metaphysics is not conceived of as a field of research about the external world but rather as one about the rules and operations of reason which structure the mental objects which the external world causes us to entertain.

The impact of Locke's and Kant's accounts of how to ground religion in reason can hardly be underestimated. Locke's argument that religious beliefs ought to be grounded in evidence developed later on into what is now known as the evidentialist objection to religious belief, that is, the view that one ought to proportion the strength of one's belief to the evidence one has for that belief. Failure to do so is dishonest and immoral, amounting to a neglect of one's epistemic duties as W. K. Clifford famously argued by claiming that "[...] it is wrong always, everywhere, and for anyone to believe anything upon insufficient evidence." (Clifford 1901/1999, 273).

6 Kant makes explicit that the postulates are not a product of mere wishful thinking but rather are necessary requirements of a practical perspective. See, for instance, the Critique of Practical Reason 143 (Of Belief from a Requirement of Pure Reason): "Now the above-mentioned postulates concern only the physical or metaphysical conditions of the possibility of the summum bonum; in a word, those which lie in the nature of things; not, however, for the sake of an arbitrary speculative purpose, but of a practically necessary end of a pure rational will, which in this case does not choose, but obeys an inexorable command of reason, the foundation of which is objective, in the constitution of things as they must be universally judged by pure reason, and is not based on inclination; [...]." 
For Locke it was still natural to think that respecting evidence leads you to rationally confirmed religious beliefs; in a largely secularized intellectual climate, however, the starting conditions are utterly different. Then it is a small step to demand that respecting one's epistemic duties in the light of a principle like the one proposed by Clifford implies a presupposition of atheism. A. Flew, for instance, proposes that "the debate about the existence of God should properly begin from the presumption of atheism, that the onus of proof must lie upon the theist." (Flew 1976, 14).

Similarly M. Scriven says that

[a]theism is obligatory in the absence of any evidence for God's existence. [...] The proper alternative, where there is no evidence, is not mere suspension of belief, e.g. about Santa Claus; it is disbelief (Scriven 1966, 103).

Once the belief in God was largely evaporated in the cultural and intellectual discourse, many philosophers in the Lockean intellectual tradition considered atheism as the default position for any rational person. For this reason, theism is presumed to be guilty of irrationality or intellectual dishonesty as long as it is not proven innocent.

Intellectuals in the shadow of Kant, by contrast, were not so much concerned with the ethics of religious belief than with its nature. They raise doubts about whether belief in God implies any belief about his existence. The most fundamental question of traditional metaphysics is "What is there?" As indicated above, however, Kantian metaphysics is an investigation less of the external world and more of one's mental concepts about that world. For Kant himself, God was not a possible item of our experience but rather a transcendental idea of theoretical reason, or a postulate of practical reason. Kaufman, for instance, in his influential book on the concept of God, distinguished between the real and the available referent of the term "God", and argued that the real referent is never accessible to us because it transcends our experience. Thus, all we have is the available referent - a concept of God which is related in some important ways to our theoretical and in particular practical purposes (Kaufman 1972, 85). 
This was the intellectual situation in which analytic philosophers of religion found themselves in the 1960s and 1970s. Religious belief was no longer considered utterly meaningless, but the prevailing view was that there is no rational justification for religious beliefs or such beliefs are not claims about existence but rather about practical purposes and existential needs.

\section{Adolescence: Arguing for the Rationality of Theistic Belief}

The dominance of the evidentialist objection, however, began to crumble in the second half of the $20^{\text {th }}$ century. The epistemological discussion was in turmoil not least due to the contributions of figures like Kuhn and Feyerabend (Kuhn 1962; Feyerabend 1975). ${ }^{7}$ A meta-epistemological discussion emerged which made philosophers aware of various alternatives to foundationalism, which itself came to be seen as seriously flawed. One major objection to foundationalism is that most of the beliefs that we take for granted in our everyday life would not qualify for the foundation of a person's belief system in the sense of being self-evident, incorrigible, or evident to the senses. Beliefs like "the world has existed for more than two hours", "I had breakfast this morning", "I am not the only person in the universe" or "There exist objects enduring through time" meet none of these criteria, even though we presuppose them in our daily life without invoking more basic beliefs to justify them. In other words, these beliefs seem to be properly basic, that is they can be justifiably held without other more basic beliefs, and a rational person seems to be justified in holding them - but foundationalism denies both of these claims. Another equally worrisome objection is that a principle of proper basicality, such as "Proposition $\mathrm{P}$ is properly basic for person $\mathrm{A}$ only if $\mathrm{P}$ is self-evident or incorrigible or evident to the senses for A", does not itself meet the conditions which it itself lays down. As a consequence, foundationalism is not free from

Just think of the groundbreaking contributions to the philosophy of science and epistemology such as Thomas Kuhn's The Structure of Scientific Revolutions (1962) and Paul Feyerabend's Against Method (1975). 
self-referential difficulties (Plantinga 1983, 59-63; Quinn 1985). ${ }^{8}$ Thus, foundationalism not only gives the wrong results, but it is also self-referentially incoherent. As long as foundationalism cannot overcome these problems, there is no obligation to stick to the foundationist's claims that belief in God cannot be properly basic and that anyone believing in God without evidence that is in this sense sufficient is neglecting her epistemic duties as a rational person.

The breakdown of foundationalism as the leading epistemological theory had further liberating effects for the development of the analytic philosophy of religion. First, philosophers were exonerated of the obligation to demonstrate that religious belief is only justified if rationally grounded according to a foundationalist model. Second, someone arguing that religious belief is irrational or epistemically unacceptable could no longer appeal to foundationalism to support his or her claim. The charge of irrationality against religious beliefs could no longer be launched from a dominating epistemological default position for all religious beliefs at once, but had to be made from a case by case basis. Third, the rejection of foundationalism led analytic philosophers of religion to investigate in what sense belief in God - if not based on other beliefs accepted by the neutral deliverance of reason - can be said to be basic and epistemically justified.

A major question in this context is: Does the claim that belief in God is properly basic imply that any belief whatsoever can be properly basic for a person? ${ }^{9}$ Plantinga and other religious epistemologists argued that there is no such implication, because criteria for proper basicality are to be developed inductively in the light of the circumstances of the believer (Plantinga 1983, 74-78).

One might worry that a failure to agree on the relevant circumstances will threaten the trap of foundationalism again - but this worry does not pan out. The arguments presented for the proper basicality of some belief

8 For a detailed discussion of both points see Plantinga (1983), 59-63. Of course, Plantinga's claims have not remainded without contradiction. See, for instance, Quinn (1985).

9 For instance, imagine a great pumpkin or a spaghetti monster as suggested by some critics of the proper basicality of religious belief. 
may in many cases be person-relative; that is, they may legitimately convince one person within his or her specific circumstances even if they do not convince another person in another context (Mavrodes 1970, 31-35). Plantinga says:

The Christian will of course suppose that belief in God is entirely proper and rational; [...]. Followers of Bertrand Russell and Madelyn Murray O'Hare may disagree; but how is that relevant? Must my criteria, or those of the Christian community, conform to their examples? Surely not. The Christian community is responsible to its set of examples, not to theirs (Plantinga 1983, 77).

Accordingly, a person can hold that belief in God is properly basic but that belief in the Great Pumpkin as creator of the universe is not - even though she lacks a clearly defined general criterion of proper basicality. Such a person is not without any means, however, to defend his or her basic belief: Proper basicality does not imply an argumentative void. If a belief is properly basic in certain conditions (and not in others) then these conditions can also be the ground of the belief's justification. The belief in God could be justified by the condition that human persons were created with a disposition to experience the creator's presence in creation. Circumstances such as the experience of natural beauty, gratitude, inner peace, guilt or forgiveness may be used as grounds to justify the belief that God exists and discloses his existence to us.

To argue that a person is in his or her epistemic rights to have a basic belief in God does not imply that arguments cannot put into question this belief. The person may encounter strong arguments against the existence of God, such as the problem of evil or of divine hiddenness. These are potential defeaters of the rationality of belief in God, and as a consequence this person needs an appropriate reply: a defeater-defeater, so to speak.

These brief reflections indicate that the line of thought put forward by Plantinga and cohorts, which is now known as "Reformed epistemology", must not be conflated with strong forms of fideism. These see a tension between reason and faith; Reformed epistemology, by contrast, considers the belief in God to be a deliverance of reason in the same boat as the as- 
sumption that other persons exist or that objects endure through time. The claim is that God has created us in such a way that we form these beliefs rationally naturally if placed in the right circumstances. For this no "leap of faith" is required. Of course, an atheist can deny that belief in God is a deliverance of reason in the first place, but this objection leads us back to the initial claim that the neutral standpoint of philosophical reason presupposed by foundationalism is unavailable.

But not all proponents of analytic philosophical theology followed the lead of Reformed epistemology and have thought that the notion of a common neutral reason is per se problematic. Richard Swinburne, for instance, embraces the idea that there is in principle one common rational standpoint available to theist and atheist alike. He does not think that the deliverances of reason lead to rational certainty, but to the correct probability values for beliefs - including the belief in God. In his Intellectual Autobiography, Swinburne explains how he came to endorse this view. He writes:

The world-view of the time [the 1950s, G. G.], however, then as now, among sophisticated intellectuals was basically anti-Christian. [...] I was appalled by the fact that the Church didn't seem to take seriously the claims and arguments of the current world-view (Swinburne 1994, 1).

Subsequently he goes on:

[...] if the modern world throws up some plausible arguments which suggest that he [God, G. G.] almost certainly doesn't exist, they need to be treated seriously and shown to be unsound (Swinburne 1994, 2).

Finally he notes:

The centre-piece of the modern world-view was [...] it seemed to me [...] modern theoretical science [...] which many people supposed to count against the traditional Christian world-view (Swinburne 1994, 4).

These brief notes suffice for grasping the thrust of Swinburne's line of argument. His starting point is the conception of neutral reason as used 
in secular philosophy and the natural sciences. He accepts the criteria by which scientists judge a theory to be well supported and meaningful or ruled out by the data. Against this background, the claims of the Christian world-view require defense as rational and with a certain probability true.

Swinburne distinguishes between scientific and personal explanations, and he thinks that both kinds are used all the time to explain the phenomena we encounter. Scientific explanations appeal to an initial state of affairs together with natural laws to explain why a certain phenomenon takes place or will most probably take place. Personal explanations refer to the purposes and aims of a person to explain his or her behavior. In addition, Swinburne argues that there is a difference of "level" between these two kinds of explanations, on the one hand, and metaphysical theories, on the other. Scientific and personal explanations each seek to explain a limited class of data ("this specific observation" or "this kind of behavior"). Metaphysical theories, in contrast, concern the highest level of explanation; they aim to be all-encompassing; that is, to explain the most general structures of reality, including what entities there are and how they relate to each other. With these distinctions to hand, Swinburne's research program was

to use the criteria of modern natural science, analysed with the careful rigour of modern philosophy, to show the meaningfulness and justification of Christian theology (Swinburne 1994, 8).

After working on confirmation theory for understanding the criteria by which scientists evaluate the quality of a theory, Swinburne began in the late 1970s to use this framework to put his research program into practice. ${ }^{10}$ In the Existence of God, ${ }^{11}$ Swinburne constructs a cumulative-case argument for God's existence. His claim is that, in the light of various ob-

10 In a nutshell, the idea is that the intrinsic probability of a single proposition - its probability independently of any evidence - rests primarily on its simplicity; this probability is then modified in the light of evidence according to the probability calculus, in particular Bayes's theorem.

11 Swinburne (1979). This is the second book of his trilogy; the other two are The Coherence of Theism (1977) and Faith and Reason (1981). 
servables such as the existence of a complex and ordered universe, the existence of conscious beings, the occurrence of certain apparently miraculous events in history and the widespread phenomenon of religious experience, theism is more probable than not.

\section{Taking stock: An interim report}

We are now in a position to take stock of the impact of these major developments in analytic philosophical theology that arose from the ashes of logical positivism in the two decades to follow. First, as outlined, the question of a rational justification of religious belief was in those days at center stage. The strategies for meeting this challenge were basically twofold: Either the assumption of a neutral conception of rationality as a common starting point was rejected as untenable, or it was accepted and used to argue that the existence of God is the most probable hypothesis to explain reality as we currently understand it. Though both accounts contrast sharply, they share the assumption - each in its own way - that a rational justification of religious belief is indispensable if philosophy of religion and systematic theology are to share a seat at the table of modern intellectual discourse. Both accounts hold that discourse about a belief system as large as what we might call one's world-view is a matter open to rational evaluation and argument, not a question of non-rational choice, and thus that argumentative rigor and logical coherence are crucial in articulating and upholding it.

Second, just as important as arguing for the rationality of religious belief per se is showing that various beliefs within areligious belief system can coherently be hold in the light of other beliefs about reality. Consider, for instance, the problem of evil as a serious objection to a Christian world-view. In his classic article Evil and Omnipotence, J. L. Mackie claimed that the existence of God is logically inconsistent with the existence of evil. According to Mackie, his argument shows that "several parts of the essential theological doctrine are inconsistent with one another." (Mackie $1955,200)$. 
Thus, even if it could be shown that religious belief per se is rational, Mackie claims that it is ensnared in logical inconsistences once combined with other propositions in a larger doctrinal system. Consequently, we still need an argument to the effect that the various tenets of a religious world-view are not only consistent with each other but also with our other knowledge about the world.

Plantinga responded to Mackie's challenge with what he called the "free will defense" (Plantinga, 1974, chap. IX). Without going into the intricate details of the argument, Plantinga claimed that, possibly, it is not within the power of an omnipotent God to create a world containing moral goodness without moral evil. The reason for this is that moral goodness can only be achieved by creatures possessing libertarian free - but, as it happens, creatures with this sort of freedom will eventually choose evil instead of good. Hence, even in light of the existence of an omnipotent and wholly good God, evil in his creation will exist, and consequently Mackie's argument of logical inconsistency fails. Similar discussions arose about other doctrines, such as God's omniscience in relation to human freedom (Pike 1965).

Thus, the decades after the end of logical positivism witnessed not only a defense of religious belief per se but their defense against accusation of falsehood on grounds of logical inconsistency. Hasker underlines this point by saying that

[i]t was necessary for theists to define the main theistic attributes as rigorously as possible and to defend the definitions as logically coherent (Hasker 2005, 427).

Accordingly, a discussion was taking shape, which continues today, about all of the attributes traditionally ascribed to God. The most prolific writer shaping this discussion is probably Swinburne. The following statement nicely summarizes the efforts that have been undertaken since then, by him and others:

The argument of Part II so far has been that it is coherent to suppose that there exists now an omnipotent spirit, who is perfectly free, the creator of the 
universe, omnipotent, omniscient, perfectly good, and a source of moral obligation - so long as 'omnipotent' and 'omniscient' are understood in somewhat restricted senses (Swinburne 1977, 217).

Third, it ought to be underlined that, the removal of the obstacles to taking religious beliefs philosophically seriously was a necessary but by no means sufficient condition for the future development of analytic philosophical theology. Once the door was wide open, also personalities are required willing to walk through. Swinburne was one such figure, Plantinga another. Telling in this context is Plantinga's decision to leave Harvard for Calvin College in order to continue to study philosophy with a confessing Christian philosopher:

Had I not returned to Calvin from Harvard, I doubt (humanly speaking, anyway) that I would have remained a Christian at all; certainly Christianity or theism would not have been the focal point of my adult intellectual life (Plantinga 1993, 53).

And in his well known 1984 presidential address to the Society of Christian Philosophers founded a few years earlier Plantinga reminds his fellow colleagues:

Christian philosophers, however, are the philosophers of the Christian community; and it is part of their task as Christian philosophers to serve the Christian community. But the Christian community has its own questions, its own concerns, its own topics for investigation, its own agenda and its own research program. Christian philosophers ought not merely take their inspiration from what's going on at Princeton or Berkeley or Harvard, attractive and scintillating as that may be; for perhaps those questions and topics are not the ones, or not the only ones, they should be thinking about as the philosophers of the Christian community (Plantinga 1984).

These excerpts suffice to give a feeling of the personal commitment of the first generation of analytic philosophers of religion to work in a Christian-philosophical spirit which was the crucial motor for the propagation of analytic philosophical theology as a serious object of philosophical study. 
Fourth, it should not be denied that the ambition to present a Christian world-view as a live intellectual option has corresponded with a rather pessimistic assessment of the state of modern theological reasoning. The most influential systematic theologians in the first two thirds of the $20^{\text {th }}$ century were German, and their philosophical upbringing was mainly influenced by German Idealism, Phenomenology and philosophers such as Nietzsche, Heidegger or those in the French tradition. Analytic philosophers consider large portions of these philosophies with a certain reserve; for, as Swinburne remarks,

what characterizes them all is a certain sloppiness of argument, a tendency to draw big, vague general pictures of the Universe, without spelling out very precisely or justifying them very thoroughly, a kind of philosophy nearer to literature than to science (Swinburne 1994, 2).

Now, one might claim that, sociologically speaking, the use of these criticized philosophical resources was obvious for theologians at this time. If we focus on the eminent figures of $20^{\text {th }}$-century German speaking theology such as Karl Barth, Karl Rahner or Wolfhart Pannenberg, we recognize that they were educated within a lively philosophical culture shaped by world-renowned philosophers writing almost exclusively in German. Analytic philosophy, in contrast, was still in its early stage, primarily science-oriented, largely hostile to religion and primarily an Anglo-American phenomenon. From this perspective it is rather a no-brainer for these theologians to draw on the rich philosophical treasures of their own culture.

Be that as it may, the contemporary attitude of analytic philosophers of religion toward modern theology, as exemplified by Swinburne's quote, is not primarily attributable to modern theologians' neglect of analytic sources. Rather, the attitude points toward a more fundamental systematic question. As I have argued, the larger narrative of analytic philosophy in general included the search for a new firm foundation of knowledge. And the empiricist strand of this enterprise, at the very least, was deeply influenced by the rise of modern natural science. Science was seen as a major 
source of this sought-after foundation. Even if many contemporary analytic philosophers hold foundationalism to be untenable, they largely accept the theoretical exigencies of scientific accounts, including a realist outlook on reality, the assumption that truth is objective, and the emphasis on precise argumentation for each assertion. ${ }^{12}$

Many modern theologians, however, do not share these assumptions or priorities. On the one hand, one often encounters statements by theologians to the effect that Kant has "shown" that we are unable to apply our concepts to reality itself, and therefore that we cannot apply them to God either. In other words, Kant is read as motivating a shift towards an anti-realist and anti-metaphysical mode of doing theology. ${ }^{13}$ On the other hand, many theologians are deeply influenced by so-called postmodernist thinking, which is highly critical of concepts such as universal science, truth or reason. The basic idea is that what counts as 'true' or 'rational' is a culturally and socially context-dependent story "told by persons in positions of power in order to perpetuate their way of seeing and organizing the natural and social world." (Vanhoozer 2003, 11).

On this view, philosophies subscribing to the ideal of objective truth and realist classificatory schemes reveal more - and something problematic naïve - about their proponents than they do about the way things actually are or are supposed to be.

If this rough presentation of modern Western philosophy is correct, then two very distinctive streams of thought are present in this philosophy: one realist and the other anti-realist. Analytic philosophy belongs to the former camp, and philosophies inspired by figures such as Kant, Nietzsche, Heidegger or Derrida belong to the latter. I confine myself to noting that exponents of contemporary analytic philosophical theology consider these

12 Rea (200), 4, characterizes the ambitions of analytic philosophy - which apply also to analytic philosophical theology - as follows: „(i) to identify the scope and limits of our powers to obtain knowledge oft he world, and (ii) to provide such true explanatory theories as we can in areas of inquiry (metaphysics, morals, and the like) that fall outside the scope of the natural sciences.

13 Chignell (2009) argues that this is only one possible reading of Kant and there are other readings available which are more congenial to analytic thought. 
postmodern maneuvers not only not their cup of tea but in fact a danger to systematic theology itself. William J. Abraham, a theologian sympathetic to analytic philosophical theology, for instance, writes:

In fact, the material content of systematic theology virtually disappeared in some quarters due to a Third Schism in the Church in which the canonical faith was deconstructed from within in the name of credibility and relevance. [...] The motives were good; theologians wanted to speak in a witting manner to the intellectual and political challenges of the day. The problem was that so little doctrinal content was left by the time the theologians were finished speaking. [...] If the deep truths of the Gospel and the central elements of the Nicene Creed are constitutive of the Christian faith, then much modern and contemporary theology is really the invention of various forms of post-Christian religion (Abraham 2009, 57).

This is one of the main worries motivating the work of advocates of analytic philosophical theology.

\section{Maturity, and some brief objections}

So far I have touched on topics such as the rationality of religious belief, the problem of evil and the divine attributes. All of these topics continue to be hotly debated, and these debates have led to further distinctions and more arguments. In addition, the topics treated have broadened considerably: whereas the primary topic of discussion was theism in general, discussions now include increasingly specific (Christian) doctrines. Swinburne serves again as a paradigm case for this shift: After finishing his trilogy on theism in the early 1980s, he began to work on a series of books devoted to specific Christian doctrines such as the atonement, revelation, trinity, the incarnation and the resurrection in the 1990s. ${ }^{14}$

It is this time when the status nascendi of analytic theology ought to be located. As I have said, there is little point in trying to distinguish sharply

14 A simple chronological ordering of Swinburne's publications makes this shift in focus apparent. 
between analytic philosophy of religion and analytic theology, particularly given the view, now shared by many analytic philosophers (and not just philosophers of religion), that there is no impetus - and possibly even no way - to base all of one's arguments on neutral reason. We may characterize analytic theology roughly as a theological model which draws on the resources of a particular philosophical tradition, analytic philosophy. As Crisp underlines, such a theological approach is "not intended as a vehicle by which theology may become enslaved to philosophy. Instead, it is a means of making sense of substantive theological claims (as well as raising substantive issues)." (Crisp 2009, 42).

Analytic theology is one proposed model of an account of faith seeking understanding - no more, but also no less. That said, I will now comment briefly on some objections raised against analytic philosophical theology as a method of this sort; I will conclude with a suggestion.

First Objection: analytic philosophical theology is a-historical: My exposition of the larger narrative in which analytic philosophical theology is embedded should have made clear that this objection is, at best, only partially correct. As indicated, many analytic philosophers of religion certainly did pay attention to the history of philosophy. These philosophers saw themselves as part of a larger tradition influenced strongly by the ideals of the Enlightenment. As Wolterstorff has put it:

[...] the situation is not that we have failed to consider the Kantian alternative, and are consequently still wandering about in unenlightened naiveté; the situation is rather that we have considered the Kantian arguments and found them wanting (Wolterstorff 2010, 25).

In addition, many spear headers of this movement are also eminent historians of philosophy. For instance, Eleonore Stump is a highly celebrated scholar of Aquinas, Marilyn McCord Adams of Ockham, and Woltertorff has written extensively on Locke and Thomas Reid.

This brings me to the second objection, which accuses analytic philosophical theology of being a mere resumption of overcome scholasticism. Clearly, there is considerable overlap between analytic philosophical the- 
ology and scholastic thinking. The turn away from both Kant and postmodern thinking makes analytic philosophical theology to a certain extent "pre-modern", and consequently a methodological confederate of scholasticism. Advocates of analytic philosophical theology see not only methodological parallels in the work of their medieval predecessors, but also many ideas worth considering. Since they do not share the wide-spread post-modern philosophical assumption of a "hermeneutics of suspicion", they have no qualms in taking the ideas of the scholastics at face value in order to enter into a systematic philosophical dialogue with them. They are thus not resuming scholastic thought but mining it for valuable insights that can enrich the contemporary systematic philosophical and theological discourse.

Third objection: Analytic philosophical theology is hermeneutically blind. Having a clear look at the cultural and sociological factors shaping traditions of thought is valuable, and thus a "hermeneutics of suspicion" can thus be illuminating and helpful. There is no doubt that postmodern philosophy contributed enormously to creating a great sensibility to these issues, especially in correlation with topics such as tolerance, liberation and justice. There is a fundamental difference, however, between being aware of the helpfulness of such a hermeneutics and making it an absolute medium of interpretation. There is good reason to take the beliefs of others at their face value and to assess the quality of these beliefs as they stand because this implies to respect the claims of truth and rational adequacy put forward by those holding these beliefs. A "hermeneutics of suspicion" is useful as a meta-tool once the honesty and communication goals of one's dialogue partner are less than clear and thus make it reasonable to call them into question.

\section{Concluding remarks}

My primary aim in this paper has been to set out a larger narrative of analytic philosophical theology, so as to better understand its research program and the motivations guiding it. I close with a tentative prospect: In Analytic Theology Mike Rea gives voice to the hope that the methodological divide between analytic philosophers of religion and (postmod- 
ern-oriented) systematic theologians is ready to be explored (Rea 2009, 1). Indeed, this divide of traditions of thought is unfortunate because each can learn from another.

Analytic philosophical theology should take more seriously the worry that its own methodological approaches are subject to ideological abuse. The focus on religion's ethical implications - such as its bearing on social and political issues - is almost entirely missing from the analytic perspective. In addition, the analytic tradition has always paid more attention to experience and the senses than to the interpretation of texts and narratives. Major sources of religious life, however, are related to the reading of, or listening to the reading and expounding of, sacred texts. Here it might be helpful for analytic thinkers to learn from their continental counterparts who are more concerned about issues pertaining to hermeneutics, textual criticism and interpretation.

Finally, there is a tendency within analytic accounts, which develop increasingly specialized discussions, to narrow instead of broaden their focus. Paying more attention to other philosophical traditions - in particular to those that are compatible with the basic research assumptions of analytic thought ${ }^{15}$ - might be a useful remedy for a philosophical discussion which gives the impression to study more and more of less and less. ${ }^{16}$

Thinkers in the so-called continental tradition, by contrast, show no particular sensibility to questions of rational adequacy and truth. This attitude is hardly comprehensible to someone who takes his or her own religious tradition as a serious live option for understanding reality and her existence in it. To such a person it matters enormously whether his or her religious beliefs are true or false. For if they are false, then all of the hopes built on it are in vain - as Paul famously underlines. ${ }^{17}$.

15 This may include phenomenological, pragmatist or process philosophical accounts, to name just a few, and exclude others such as extreme deconstructivist and psychoanalytic accounts.

16 Stump (2010), chap. 2, criticizes this narrowness and accuses analytic philosophy of suffering from cognitive hemianopia. She argues that it is largely blind to that part of reality "that includes the complex, nuanced thought, behavior, and relations of persons" (25).

171 Cor $15,13-14$. 
Analytic theology has the merit of focusing precisely on clarifying the contents of religious claims and evaluating the reasons for and against their truth. Of course, someone who is uninterested in these merits may find this methodological approach cumbersome and uncongenial. In this case, however, one might wonder in what alternative intellectual currency - if not precise and coherent argument - one might pursue a scholarly debate at all.

\section{References}

Abraham, William J. 2009. „Systematic Theology as Analytic Theology“, in Mike C. Rea and Oliver Crisp (eds.) Analytic Theology. New Essays in the Philosophy of Theology. Oxford: Oxford University Press, 54-69.

Carnap, Rudolf. 1932. „Überwindung der Metaphysik durch logische Analyse der Sprache“, in: Erkenntnis 2, 219-241. English translation by Arthur Pap in A. J. Ayer (ed.): Logical Positivism. Glencoe, IL: Free Press, 60-81.

Chignell, Andrew. 2009. “'As Kant has shown...”, in: Mike C. Rea and Oliver Crisp (eds.) Analytic Theology. New Essays in the Philosophy of Theology. Oxford: Oxford University Press, 117-135.

Clifford, William K. 1999. “The Ethics of Belief”, in: Eleonore Stump and Michael J. Murray (ed.) Philosophy of Religion: The Big Questions. Malden, Mass.: Blackwell 1999, 269-273. Reprinted from: Clifford, William K: Lectures and Essays. New York: MacMillan 1901, 163-176.

Crisp, Oliver. 2009. “On Analytic Theology”, in: Mike C. Rea and Oliver Crisp (eds.) Analytic Theology. New Essays in the Philosophy of Theology. Oxford: Oxford University Press, 33-53.

Flew, Anthony and MacIntyre, Alasdair (eds.). 1955. New Essays in Philosophical Theology. New York: MacMillan.

Flew, Anthony. 1976. The Presumption of Atheism. London: Pemberton.

Hasker, William. 2005. “Analytic Philosophy of Religion”, in: William J. Wainwright (ed.) The Oxford Handbook of Philosophy of Religion. Oxford: Oxford University Press, 421-446.

Hempel, Carl Gustav. 1955. "Problems and Changes in the Empiricist Criterion of Meaning”, in: Revue Internationale de Philosophie 41, 41-63.

Kaufman, Gordon. 1972. God the Problem. Cambridge: Harvard University Press. Kant, Immanuel. The Critique of Practical Reason. Translated by Thomas Kingsmill Abbott. 
http://www.gutenberg.org/cache/epub/5683/pg5683-images.html

Kant, Immanuel. The Critique of Pure Reason. Translated by J. M. D. Meiklejohn.

http://www.gutenberg.org/files/4280/4280-h/4280-h.htm

Kant, Immanuel. Prolegomena to Any Future Metaphysics That Will Be Able to Present Itself as a Science. Based on the 1902 translation by Paul Carus.

http://www.webexhibits.org/causesofcolor/ref/Kant.html

Locke, John. Of the Conduct of the Understanding. Online source: http://www.earlymoderntexts.com/assets/pdfs/locke1706.pdf

Mackie, John L. 1955. „Evil and Omnipotence“, in: Mind 64, 200-212.

Mavrodes, George. 1970. Belief in God. A Study in the Epistemology of Religion. New York: Random House.

Pike, Nelson. 1965. “Divine Omniscience and Voluntary Action”, in: The Philosophical Review 74/1, S. 27-46.

Plantinga, Alvin. 1974. The Nature of Necessity. Oxford: Clarendon Press.

Plantinga, Alvin. 1983. "Reason and Belief in God”, in: Plantinga Alvin and Wolterstorff, Nicholas (eds.): Faith and Rationality. Reason and Belief in God. Notre Dame University Press, 16-93.

Plantinga, Alvin. 1984. "Advice to Christian Philosophers”, in: Faith and Philosophy 1/3 , 253-271. http://www.faithandphilosophy.com/article_advice.php

Plantinga, Alvin. 1993. “Spiritual Autobiography“, in: Kelly James Clark (ed.) Philosophers Who Believe in God. The Spiritual Journey of 11 Leading Thinkers. Downers Grove, IL: InterVarsity Press, 45-82.

Pouviet, Roger. 2011. “On the Polish Roots of the Analytic Philosophy of Religion”, in: European Journal for Philosophy of Religion 3/1, 1-20.

Quinn, Philip L. 1985. "In the Search of the Foundations of Theism”, in: Faith and Philosophy 2/4, 469-486.

Rea, Michael C. 2009. “Introduction”, in: Mike C. Rea and Oliver Crisp (eds.) Analytic Theology. New Essays in the Philosophy of Theology. Oxford: Oxford University Press, 1-30.

Scriven, Michael. 1966. Primary Philosophy. New York: McGraw-Hill.

Stump, Eleonore. 2010. Wandering in Darkness. Narrative and the Problem of Suffering. Oxford: Oxford University Press.

Swinburne, Richard. 1977. The Coherence of Theism. Oxford: Oxford University Press.

Swinburne, Richard. 1979. The Existence of God. Oxford: Oxford University Press.

Swinburne, Richard. 1994. “Intellectual Autobiography”, in: Allan G. Padgett (ed.) Reason and the Christian Religion. Essays in honour of Richard Swinburne. Oxford: Clarendon Press, 1-18. 
Vanhoozer, Kevin J. 2003. “Theology and the condition of postmodernity: a report on knowledge (of God)", in: Vanhoozer, Kevin J (ed.) The Cambridge Companion to Postmodern Theology. Cambridge: Cambridge University Press, 3-25.

Wissenschaftliche Weltauffassung: der Wiener Kreis.

Veröffentlichungen des Vereins Ernst. 1929. Wien: Artur Wolf Verlag.

Online source: (last access on 16.10.2015): http://neurath.umcs.lublin.pl/manifest. pdf

Wolterstorff, Nicholas. 1996. John Locke and the Ethics of Belief (Cambridge Studies in religion and critical thought 2). Cambridge University Press.

Wolterstorff, Nicholas. 2009. "How Philosophical Theology Became Possible within the Analytic Tradition of Philosophy”, in: Mike C. Rea and Oliver Crisp (eds.) Analytic Theology. New Essays in the Philosophy of Theology. Oxford: Oxford University Press, 155-168.

Wolterstorff, Nicholas. 2010. “Analytic Philosophy of Religion: Retrospect and Prospect”, in: T. Lehtonen and T. Koistenen (eds.) Perspectives in Contemporary Philosophy of Religion. Helsinki: Luther-Agricola Society. Reprinted in: T. Cuneo (ed.) Inquiring about God. Selected Essays. Volume I. Cambridge: Cambridge University Press, 17-34. 
